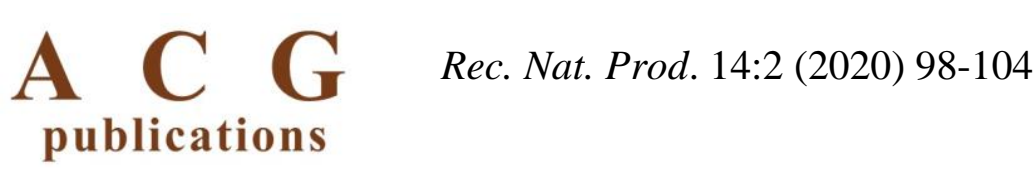

\title{
A New 2,2'-dipyridine and Its Analogues from Endophytic Streptomyces sp. KIB H017c with Potent Cytotoxicity
}

\author{
Xiao-Yan Ma 1,2*, Feng-Xian Yang ${ }^{2,3}$ Can Su${ }^{2}$, Yijun Yan ${ }^{2}$ and \\ Sheng-Xiong Huang ${ }^{*} * 2$
}

\author{
${ }^{1}$ School of Chemical Engineering, Sichuan University of Science \& Engineering, \\ Zigong, 643000, PR China. \\ ${ }^{2}$ State Key Laboratory of Phytochemistry and Plant Resources in West China, CAS Center for \\ Excellence in Molecular Plant Sciences, Kunming Institute of Botany, Chinese Academy of Sciences, \\ Kunming 650204, China. \\ ${ }^{3}$ University of the Chinese Academy of Sciences, Beijing 100049, China.
}

(Received May 03, 2019; Revised July 29, 2019; Accepted August 20, 2019)

\begin{abstract}
A new 2,2'-dipyridyl compound 1, along with three known analogues (2-4), was isolated from the culture broth of endophytic Streptomyces sp. KIB H017c derived from Fragaria ananassa. Their structures were elucidated by analysis of 1D and 2D NMR as well as HRESIMS data, and comparison with literature data. The biological properties of all isolates were explored for antibacterial, antifungal and cytotoxic activity. All four compounds exhibited weak antifungal activity against Saccharomyces cerevisiae, and compound $\mathbf{4}$ exhibited weak antifungal activity against Penicillium decumbens ATCC 10436. Compound 3 displayed moderate cytotoxic activity against HL-60 (human myeloid leukemia), SMMC-7721 (hepatocellular carcinoma), A-549 (lung carcinoma), MCF-7 (breast adenocarcinoma), and SW480 (colon carcinoma) with $\mathrm{IC}_{50}$ values of 12.10, $11.15,23.64,31.13$ and $14.62 \mu \mathrm{M}$, respectively. Compound $\mathbf{4}$ exhibited potent activity against A-549 (lung carcinoma), MCF-7 (breast adenocarcinoma), and SW480 (colon carcinoma) with $\mathrm{IC}_{50}$ values $0.88,0.34$ and $0.55 \mu \mathrm{M}$, respectively.
\end{abstract}

Keywords: Endophytic Streptomyces; 2,2'-dipyridine; antimicrobial activity; cytotoxicity. (c) 2019 ACG Publications. All rights reserved.

\section{Introduction}

Endophytic microorganisms are recognized as an abundant and dependable source of bioactive and chemically novel compounds with potential for exploitation in a wide variety of medical, agricultural, and industrial arenas [1]. Endophytic microorganisms are to be found in virtually every plant on earth. Commonly, several to hundreds of endophyte species can be isolated from a single plant [2]. Noteworthily, nearly 300,000 plant species that exist on the earth, each individual plant is considered to host one or more type of endophytes [3], which could creat an enormous biodiversity. Endophytes have attracted increasing attention from those seeking for new pharmaceutically useful products in recent years. More than 33,500 biologically active compounds have been obtained from

* Corresponding author:

E-Mail: sxhuang@mail.kib.ac.cn (S.-X. Huang); Phone:086-871-65215112 Fax: 086-871-65215112

The article was published by ACG Publications

http://www.acgpubs.org/journal/records-of-natural-products March-April 2020 EISSN:1307-6167

DOI: http://doi.org/10.25135/rnp.147.19.05.1268 
microbes by the end of 2010. Among them, $40 \%$ were produced by actinobacteria, especially the excellent producers in the genus Streptomyces [4].

With the aim of discovering new biologically active agents from endophytic actinomycetes [5,6,7], we isolated a Streptomyces sp. KIB H017c from a healthy Fragaria ananassa collected in Wenshan, Yunnan Province, China in 2014. In this report, we describe the isolation and structure elucidation of a new compound $\mathbf{1}$ as a 2,2'-dipyridyl derivative, and together with three known analogues (2-4) from the culture broth of KIB H017c. All isolates were evaluated for their antimicrobial and cytotoxic activity.

\section{Materials and Methods}

\subsection{General}

The UV data was detected by Shimadzu UV-2401PC (Shimadzu Corp., Japan). NMR spectra were recorded on Bruker Avance III 600 (Bruker Corp., Switzerland) with ${ }^{1} \mathrm{H}$ NMR at $600 \mathrm{MHz}$ and ${ }^{13} \mathrm{C}$ NMR at $150 \mathrm{MHz}$. Chemical shifts were reported in units of ppm and referenced to solvent residual in both ${ }^{1} \mathrm{H}$ NMR and ${ }^{13} \mathrm{C}$ NMR spectra, coupling constants $(J)$ were expressed in $\mathrm{Hz}$. HRESIMS analysis was carried out on an Agilent 1290 UPLC/6540 Q-TOF mass spectrometer, and general ESIMS on a Waters Xevo TQ-S spectrometer. Preparative HPLC separations were performed on a CXTH system, equipped with a UV3000 detector set at $203 \mathrm{~nm}$ (Beijing Chuangxintongheng Instruments Co. Ltd., China) and a MCI column (310 $\mathrm{mm} \times 26 \mathrm{~mm} \mathrm{I}$. D.) at a column temperature of $28{ }^{\circ} \mathrm{C}$. Semipreparative HPLC was conducted on a Hitachi Chromaster system (Hitachi Ltd., Japan) equipped with an YMC-Triart $\mathrm{C} 18$ column $(250 \times 10 \mathrm{~mm}$ i.d., $5 \mu \mathrm{m})$, at a column temperature of 28 ${ }^{\circ} \mathrm{C}$, and detection was performed with a DAD detector. The chromatographic silica gel (200-300 mesh) was supplied by Qingdao Marine Chemical Inc., China and Sephadex LH-20 (25-100 $\mu \mathrm{m})$ was supplied by Pharmacia Biotech Ltd., Sweden. Thin-layer chromatography (TLC) was performed using precoated silica gel GF254 plates (0.25 mm in thickness, Qingdao Marine Chemical Inc., China) with various solvent systems, and spots were visualized by UV light $(254 \mathrm{~nm})$ and colorized using iodine, or by heating after spraying with $10 \% \mathrm{H}_{2} \mathrm{SO}_{4}$ in $\mathrm{MeOH}$.

\subsection{Biological Material}

The Strain KIB H017c was isolated from a healthy Fragaria ananassa plant collected at east longitude $104^{\circ} 20^{\prime} 46.0^{\prime \prime}$, north latitude $23^{\circ} 17^{\prime} 39.0^{\prime \prime}$ in Wenshan, Yunnan Province, China in 2014. Its 16S rRNA gene sequence (GenBank accession No. MK049995) of this strain showed a $99 \%$ identity to Streptomyces sp. S8 (GenBank accession No. CP015362). Pathogenic bacteria strains were provided by North West Agriculture and Forestry University, Xi'an. Strains have been saved in the State Key Laboratory of Phytochemistry and Plant Resources in West China, CAS Center for Excellence in Molecular Plant Sciences, Kunming Institute of Botany, Chinese Academy of Sciences.

\subsection{Fermentation and Isolation}

The seed medium was prepared in $250 \mathrm{~mL}$ baffle Erlenmeyer flasks. Each flask was filled with $50 \mathrm{~mL}$ of Tryptone Soy Broth $\left(30 \mathrm{~g} / \mathrm{L}, \mathrm{pH}\right.$ was not adjusted) and cultivated for 48 hours at $28{ }^{\circ} \mathrm{C}$ on a rotary shaker $(200 \mathrm{rpm})$. Fermentations were carried out in $1000 \mathrm{~mL}$ baffle Erlenmeyer flasks. Each flask was filled with $250 \mathrm{~mL}$ of medium consisting of Tryptone $0.5 \%$, yeast extract $0.5 \%$, soluble starch $1 \%$, D-glucose $1 \%$, Glycerol $1 \%$ and $\mathrm{CaCO}_{3} 0.3 \%$ in deionized $\mathrm{H}_{2} \mathrm{O}$ (pH was adjusted to 7.0 ). Every fermentation flask was inoculated with $10 \mathrm{~mL}$ seed medium and cultivated for 7 days at $28{ }^{\circ} \mathrm{C}$ on a rotary shaker $(200 \mathrm{rpm})$. The culture broth $(15 \mathrm{~L})$ was centrifuged $(4000 \mathrm{rpm}, 20 \mathrm{~min})$ and the liquid supernatant was extracted with ethyl acetate $(6 \times 5 \mathrm{~L})$ and concentrated in vacuo, while the mycelium was extracted with acetone $(3 \times 0.5 \mathrm{~L})$ and concentrated in vacuo, then partitioned with ethyl acetate twice and concentrated. Both organic parts were combined and evaporated to remove the solvent. The residue $(1.5 \mathrm{~g})$ was subjected to silica gel column chromatography. Elution with petroleum ether-ethyl acetate $(90: 10,50: 50$ and 0:100 v/v) and $\mathrm{MeOH}$ yielded three fractions $\mathrm{A}$ to $\mathrm{C}$. 
Fraction B (1.0 g) was further separated using preparative HPLC on an MCI column into fractions B-1 to B-4, by elution with $\mathrm{MeOH}(25 \%, 50 \%, 75 \%$ and $100 \%$ in water) using a flow rate of $12 \mathrm{~mL} / \mathrm{min}$. Fraction B-3 was further separated by Sephadex LH-20 chromatography (MeOH) into fractions B-3-1 to B-3-3. Fraction B-3-2 was subjected to semipreparative HPLC (Hitachi HPLC system, YMC-Triart C18 column, $250 \times 10 \mathrm{~mm}$, DAD detector) using a flow rate of $3 \mathrm{~mL} / \mathrm{min}$ and isocratic elution with $35 \% \mathrm{MeOH}$ in $\mathrm{H}_{2} \mathrm{O}$, and yielded $1(4.0 \mathrm{mg})$ and $2(3.0 \mathrm{mg})$. Fraction $\mathrm{B}-4$ was soluble in chloroform and methanol $(1: 1, \mathrm{v} / \mathrm{v})$, and yielded colourless crystals after evaporation of the solvent. Repeated washing of the crystals with ethyl acetate and $\mathrm{MeOH}$, yielded compound $3(10 \mathrm{mg})$. The residue of fraction B-4 was subjected to semipreparative HPLC with isocratic elution with $75 \% \mathrm{MeOH}$ in $\mathrm{H}_{2} \mathrm{O}$ at a flow rate of $3 \mathrm{~mL} / \mathrm{min}$, yielded compound $4(3.0 \mathrm{mg}$ ) (see supporting information for detailed procedure).<smiles>COc1cc(-c2ccccn2)nc(C(N)=O)c1[SiH3]</smiles>

1<smiles>COc1cc(-c2ccccn2)nc([Al])c1S(C)=O</smiles>

2<smiles>COc1cc(-c2ccccn2)nc([14CH3])c1[Hg]</smiles>

3<smiles>COc1cc(-c2ccccn2)nc2cnsc12</smiles>

4

Figure 1. Chemical structure of compounds 1-4

\subsection{Antimicrobial Activity Test}

For plate diffusion assays [8], $20 \mu \mathrm{g}$ of the isolated compounds were dissolved in acetone and dropped on paper disks $(\varnothing 5 \mathrm{~mm}$, thickness $0.5 \mathrm{~mm}$ ). These were dried under sterile conditions and placed on agar plates inoculated with the testing organism (two fungi strains, Saccharomyces cerevisiae and Penicillium decumbens ATCC 10436, two bacteria strains, Escherichia coli ATCC 8099 and Staphylococcus aureus ATCC 6538). The plates were cultivated at $37{ }^{\circ} \mathrm{C}$ (bacteria) for $12 \mathrm{~h}$ or $28{ }^{\circ} \mathrm{C}$ (fungi) for $48 \mathrm{~h}$, and the inhibition zones were measured. Kanamycin $(10 \mu \mathrm{g} / \mathrm{disk})$ and nystatin $(10 \mu \mathrm{g} /$ disk $)$ were used as positive control for bacteria and fungi, respectively. Each test was performed four times.

\subsection{Cytotoxicity Activity Test}

The cytotoxicity of compounds 1-4 against the tumor cell lines HL-60 (human myeloid leukemia), SMMC-7721 (hepatocellular carcinoma), A-549 (lung carcinoma), MCF-7 (breast adenocarcinoma), and SW480 (colon carcinoma) were assessed using the MTS method [9]. Cisplatin (Sigma, 99\% purity) and Paclitaxel (Taxol, Sigma, 97\% purity) were used as positive controls. Briefly, all cells were cultured in RPMI-1640 or DMEM medium (Hyclone, Logan, UT, USA), which were supplemented with $10 \%$ fetal bovine serum (Hyclone, USA) at $37{ }^{\circ} \mathrm{C}$ in a humidified atmosphere containing $5 \% \mathrm{CO}_{2}$. Cells were seeded at $1 \times 10^{4}$ cells per well into 96-well cell culture plates and then incubated at $37{ }^{\circ} \mathrm{C}$ for $12 \sim 24 \mathrm{~h}$. The tested compounds of different concentrations $(0.064,0.32$, $1.6,8.0,40 \mu \mathrm{M}$ ) were added into the 96 -well plates and cultivated for $48 \mathrm{~h}$. Then $20 \mu \mathrm{L}$ of MTS was added to each well and the incubation continued for $4 \mathrm{~h}$ at $37{ }^{\circ} \mathrm{C}$. Finally, the optical density was measured at $492 \mathrm{~nm}$ using a Multiskan FC plate reader (Thermo Scientific, USA). The $\mathrm{IC}_{50}$ value of each compound was calculated by the Reed and Muench's method [10]. 


\section{Results and Discussion}

\subsection{Structure Elucidation}

Compound 1 was obtained as white powder, and assigned a molecular formula of $\mathrm{C}_{13} \mathrm{H}_{13} \mathrm{~N}_{3} \mathrm{O}_{2} \mathrm{~S}$ from its HRESIMS data $\left(\mathrm{m} / z 276.0808\left[\mathrm{M}+\mathrm{H}^{+}\right]\right.$, calcd for 276.0801), requiring 9 degrees of unsaturation. Analysis of the ${ }^{13} \mathrm{C}$ NMR data and HSQC spectrum for 1 revealed six quaternary carbons, five methine carbons, and two methyl carbon including a methoxy group $\left(\delta_{\mathrm{H}} 4.05, \delta_{\mathrm{C}} 56.4\right)$ and a methylthio group $\left(\delta_{\mathrm{H}} 2.33, \delta_{\mathrm{C}} 17.6\right)$. The $\mathrm{H}-\mathrm{H}$ COSY spectrum of 1 indicated a sequence correlation of $3^{\prime}-\mathrm{H}(\delta 8.39), 4^{\prime}-\mathrm{H}(\delta 7.95), 5^{\prime}-\mathrm{H}(\delta 7.48)$ and $6^{\prime}-\mathrm{H}(\delta 8.70)$, and the HMBC spectrum indicated correlations from $3^{\prime}-\mathrm{H}, 4^{\prime}-\mathrm{H}$ and $6^{\prime}-\mathrm{H}$ to $2^{\prime}-\mathrm{C}(\delta 154.4)$, revealing the presence of a 2-pyridyl group. Further comparison of NMR spectra with SF2738A [11] indicated that compound 1 has a similar 2,2'-dipyridyl skeleton, and the only difference was the substituent at 6 . As shown in Figure 2 and Table 1, the HMBC experiments (correlations from $\mathrm{H}-3^{\prime}$ to $\mathrm{C}-2$, from $\mathrm{H}-3$ to $\mathrm{C}-2^{\prime}$, from $\delta_{\mathrm{H}} 4.05$ $\left(4-\mathrm{OCH}_{3}\right)$ to $\mathrm{C}-4$ and from $\delta_{\mathrm{H}} 2.33\left(5-\mathrm{SCH}_{3}\right)$ to $\left.\mathrm{C}-5\right)$ revealed that $\mathbf{1}$ consists of a tetra-substituted pyridine with 2-pyridyl, methoxyl, methylthio and one additional group at positions 2, 4, 5 and 6, respectively. The remaining group was deduced to be an amide group by HMBC correlations from $\delta_{\mathrm{H}}$ 7.94 and $\delta_{\mathrm{H}} 7.57$ to $\delta_{\mathrm{C}} 168.9(\mathrm{C}-7)$, and $\delta_{\mathrm{H}} 7.57(1 \mathrm{H}, \mathrm{s})$ to $\delta_{\mathrm{C}} 158.2(\mathrm{C}-6)$ in Figure 2 . From the foregoing evidence, compound $\mathbf{1}$ was established as shown in Figure 1.

Table 1. ${ }^{1} \mathrm{H}(600 \mathrm{MHz})$ and ${ }^{13} \mathrm{C}$ NMR $(150 \mathrm{MHz})$ data of compound 1 in DMSO- $d_{6}$

\begin{tabular}{ccl}
\hline Position & $\boldsymbol{\delta} \mathbf{c}(\mathbf{p p m})$ & \multicolumn{1}{c}{$\boldsymbol{\delta}_{\mathbf{H}}(\mathbf{p p m}, \boldsymbol{J}$ in $\mathbf{H z})$} \\
\hline 2 & $155.5(\mathrm{C})$ & \\
3 & $103.4(\mathrm{CH})$ & $8.02(1 \mathrm{H}, \mathrm{s})$ \\
4 & $166.7(\mathrm{C})$ & \\
$4-\mathrm{OCH}_{3}$ & $56.4\left(\mathrm{CH}_{3}\right)$ & $4.05(3 \mathrm{H}, \mathrm{s})$ \\
5 & $118.5(\mathrm{C})$ & \\
$5-\mathrm{SCH}_{3}$ & $17.6\left(\mathrm{CH}_{3}\right)$ & $2.33(3 \mathrm{H}, \mathrm{s})$ \\
6 & $158.2(\mathrm{C})$ & \\
7 & $168.9(\mathrm{C})$ & \\
$7-\mathrm{NH}_{2}$ & & $7.94(1 \mathrm{H}, \mathrm{m})$ \\
& & $7.57(1 \mathrm{H}, \mathrm{s})$ \\
$2^{\prime}$ & $154.4(\mathrm{C})$ & \\
$3^{\prime}$ & $121.1(\mathrm{CH})$ & $8.39(1 \mathrm{H}, \mathrm{d}, J=7.8 \mathrm{~Hz})$ \\
$4^{\prime}$ & $137.5(\mathrm{CH})$ & $7.96(1 \mathrm{H}, \mathrm{td}, J=7.8,1.2 \mathrm{~Hz})$ \\
$5^{\prime}$ & $124.8(\mathrm{CH})$ & $7.48(1 \mathrm{H}, \mathrm{ddd}, J=7.2,4.8,1.2 \mathrm{~Hz})$ \\
$6^{\prime}$ & $149.3(\mathrm{CH})$ & $8.70(1 \mathrm{H}, \mathrm{d}, J=4.2 \mathrm{~Hz})$ \\
\hline
\end{tabular}

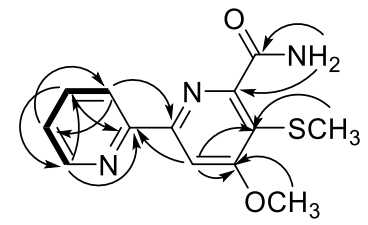

Figure 2. Key HMBC correlations of compound 1

Additionally, three known compounds were obtained (Figure 1). Compound 2 was isolated as a white powder, its ESI-MS spectrum showed a molecular ion peak at $\mathrm{m} / z 274[\mathrm{M}+\mathrm{H}]^{+}$. Compound 3 was isolated as colourless needle crystal $\left(\mathrm{CHCl}_{3} / \mathrm{CH}_{3} \mathrm{OH} 1: 1\right.$, v/v), its ESI-MS spectrum showed a molecular ion peak at $\mathrm{m} / z 258[\mathrm{M}+\mathrm{H}]^{+}$. Compound 3 was isolated as white powder, its ESI-MS spectrum showed a molecular ion peak at $m / z 244[\mathrm{M}+\mathrm{H}]{ }^{+} .{ }^{1} \mathrm{H}$ NMR and ${ }^{13} \mathrm{C}$ NMR spectroscopic data of compound 2-4 were summarized in Table 2. Compound 2-4 were proved to be pyrisulfoxin B [12], SF2738D and SF2738F [11] by direct comparison of the data with those from the literature. 
Table 2. ${ }^{1} \mathrm{H}(600 \mathrm{MHz})$ and ${ }^{13} \mathrm{C}$ NMR $(150 \mathrm{MHz})$ data of compound 2 in $\mathrm{CDCl}_{3}$ and compounds 3-4 in DMSO- $d_{6}$.

\begin{tabular}{|c|c|c|c|c|c|c|}
\hline \multirow[b]{2}{*}{ Position } & \multicolumn{2}{|c|}{ Pyrisulfoxin B (2) } & \multicolumn{2}{|c|}{ SF2738D (3) } & \multicolumn{2}{|c|}{ SF2738F (4) } \\
\hline & $\delta \mathrm{c}(\mathrm{ppm})$ & $\begin{array}{c}\delta_{\mathrm{H}}(\mathrm{ppm}, \\
\boldsymbol{J} \text { in } \mathrm{Hz}) \\
\end{array}$ & $\delta c(p p m)$ & $\begin{array}{c}\delta_{\mathrm{H}}(\mathbf{p p m}, \\
J \text { in Hz) }\end{array}$ & $\delta \mathbf{c}(\mathbf{p p m})$ & $\begin{array}{c}\delta_{\mathrm{H}}(\mathrm{ppm}, \\
J \text { in } \mathrm{Hz}) \\
\end{array}$ \\
\hline 2 & $161.2(\mathrm{C})$ & & $157.9(\mathrm{C})$ & & $158.7(\mathrm{C})$ & \\
\hline 3 & $106.6(\mathrm{CH})$ & $8.31(1 \mathrm{H}, \mathrm{s})$ & $106.3(\mathrm{CH})$ & $8.16(1 \mathrm{H}, \mathrm{s})$ & $100.0(\mathrm{CH})$ & $8.15(1 \mathrm{H}, \mathrm{s})$ \\
\hline 4 & $164.6(\mathrm{C})$ & & $167.1(\mathrm{C})$ & & $160.2(\mathrm{C})$ & \\
\hline $4-\mathrm{OCH}_{3}$ & $57.0\left(\mathrm{CH}_{3}\right)$ & $4.17(3 \mathrm{H}, \mathrm{s})$ & $57.0\left(\mathrm{CH}_{3}\right)$ & $4.09(3 \mathrm{H}, \mathrm{s})$ & $56.8\left(\mathrm{CH}_{3}\right)$ & $4.19(3 \mathrm{H}, \mathrm{s})$ \\
\hline 5 & $131.8(\mathrm{C})$ & & $127.1(\mathrm{C})$ & & $135.3(\mathrm{C})$ & \\
\hline $5-\mathrm{XCH}_{3}$ & $\begin{array}{c}39.9 \\
\left(5-\mathrm{SOCH}_{3}\right)\end{array}$ & $\begin{array}{l}3.11(3 \mathrm{H}, \mathrm{s}, \\
\left.5-\mathrm{SOCH}_{3}\right)\end{array}$ & $\begin{array}{c}17.4 \\
\left(5-\mathrm{SCH}_{3}\right)\end{array}$ & $\begin{array}{l}2.55(3 \mathrm{H}, \mathrm{s}, \\
\left.5-\mathrm{SCH}_{3}\right)\end{array}$ & & \\
\hline 6 & $137.4(\mathrm{C})$ & & 137.9 (C) & & $153.9(\mathrm{C})$ & \\
\hline 7 & $114.5(\mathrm{C})$ & & $116.6(\mathrm{C})$ & & $157.1(\mathrm{CH})$ & $9.35(1 \mathrm{H}, \mathrm{s})$ \\
\hline $2^{\prime}$ & $152.8(\mathrm{C})$ & & $153.0(\mathrm{C})$ & & $154.6(\mathrm{C})$ & \\
\hline $3^{\prime}$ & $122.2(\mathrm{CH})$ & $\begin{array}{l}8.52(1 \mathrm{H}, \mathrm{d}, \\
J=7.8 \mathrm{~Hz})\end{array}$ & $121.2(\mathrm{CH})$ & $\begin{array}{l}8.31(1 \mathrm{H}, \mathrm{d}, \\
J=7.8 \mathrm{~Hz})\end{array}$ & $121.2(\mathrm{CH})$ & $\begin{array}{l}8.50(1 \mathrm{H}, \mathrm{d}, \\
J=8.4 \mathrm{~Hz})\end{array}$ \\
\hline $4^{\prime}$ & $137.4(\mathrm{CH})$ & $\begin{array}{l}7.88(1 \mathrm{H}, \mathrm{t} \\
J=7.2 \mathrm{~Hz})\end{array}$ & $136.2(\mathrm{CH})$ & $\begin{array}{l}7.98(1 \mathrm{H}, \mathrm{td} \\
J=7.8,1.8 \mathrm{~Hz})\end{array}$ & $137.8(\mathrm{CH})$ & $\begin{array}{l}8.02(1 \mathrm{H}, \mathrm{td} \\
J=7.8,1.8 \mathrm{~Hz})\end{array}$ \\
\hline $5^{\prime}$ & $125.6(\mathrm{CH})$ & $\begin{array}{l}7.42(1 \mathrm{H}, \mathrm{dd}, \\
J=6.6,5.4 \mathrm{~Hz})\end{array}$ & $125.5(\mathrm{CH})$ & $\begin{array}{l}7.53(1 \mathrm{H}, \mathrm{ddd}, J \\
=7.8,4.8,1.2 \mathrm{~Hz})\end{array}$ & $125.2(\mathrm{CH})$ & $\begin{array}{l}7.56(1 \mathrm{H}, \mathrm{ddd}, J \\
=7.8,4.8,1.2 \mathrm{~Hz})\end{array}$ \\
\hline $6^{\prime}$ & $149.2(\mathrm{CH})$ & $\begin{array}{l}8.68(1 \mathrm{H}, \mathrm{d} \\
J=4.2 \mathrm{~Hz})\end{array}$ & $149.6(\mathrm{CH})$ & $\begin{array}{l}8.72(1 \mathrm{H}, \mathrm{ddd}, J \\
=4.8,1.8,1.2 \mathrm{~Hz})\end{array}$ & $149.4(\mathrm{CH})$ & $\begin{array}{l}8.75(1 \mathrm{H}, \mathrm{d} \\
J=4.2 \mathrm{~Hz})\end{array}$ \\
\hline
\end{tabular}

\subsection{Antimicrobial and Cytotoxicity Activity}

The isolated compounds 1-4 were evaluated for antimicrobial activity. All isolates at the concentration of $20 \mu \mathrm{g} /$ disk exhibited minor antifungal activity against Saccharomyces cerevisiae, and compound 4 exhibited minor antifungal activity against Penicillium decumbens ATCC 10436. The diameters of the inhibition zones ranged between 10 and $11 \mathrm{~mm}$, all compounds (20 $\mu \mathrm{g} / \mathrm{disk})$ were significantly less potent than the positive control, kanamycin $(10 \mu \mathrm{g} / \mathrm{disk})$ and nystatin $(10 \mu \mathrm{g} / \mathrm{disk})$ (Table 3).

Table 3. Antimicrobial activity of compounds $\mathbf{1}-\mathbf{4}^{\mathrm{a}, \mathrm{b}}(\mathrm{mm})$

\begin{tabular}{|c|c|c|c|c|c|c|}
\hline Test organism & $\begin{array}{c}\mathbf{1} \\
(20 \mu \mathrm{g} / \mathrm{disk}) \\
\end{array}$ & $\begin{array}{c}\mathbf{2} \\
(20 \mu \mathrm{g} / \mathrm{disk}) \\
\end{array}$ & $\begin{array}{c}\mathbf{3} \\
(20 \mu \mathrm{g} / \mathrm{disk}) \\
\end{array}$ & $\begin{array}{c}\mathbf{4} \\
(20 \mu \mathrm{g} / \mathrm{disk}) \\
\end{array}$ & $\begin{array}{l}\text { Kanamycin } \\
(10 \mu \mathrm{g} / \mathrm{disk})\end{array}$ & $\begin{array}{c}\text { Nystatin } \\
(10 \mu \mathrm{g} / \text { disk })\end{array}$ \\
\hline $\begin{array}{c}\text { Saccharomyces } \\
\text { cerevisiae }\end{array}$ & 11 & 10 & 10 & 11 & - & 14 \\
\hline $\begin{array}{c}\text { Penicillium } \\
\text { decumbens } \\
\text { ATCC } 10436\end{array}$ & - & - & - & 10 & - & 10 \\
\hline $\begin{array}{c}\text { Escherichia coli } \\
\text { ATCC } 8099\end{array}$ & - & - & - & - & 15 & - \\
\hline $\begin{array}{c}\text { Staphylococcus } \\
\text { aureus ATCC } \\
6538\end{array}$ & - & - & - & - & 15 & - \\
\hline
\end{tabular}

Diameter of inhibition zones in the plate diffusion assay in mm. "-" No activity

${ }^{\mathrm{b}}$ Data given were from four duplicates.

Investigation of antiproliferative activity of compounds 1-4 was carried out using an MTS assay on five human cancer cell lines: HL-60 (human myeloid leukemia), SMMC-7721 (hepatocellular carcinoma), A-549 (lung carcinoma), MCF-7 (breast adenocarcinoma) and SW480 (colon carcinoma). Compounds $\mathbf{1}$ and $\mathbf{2}$ exhibited no obvious antiproliferative activities against the five cancer cell lines ( $\mathrm{IC}_{50}>40 \mu \mathrm{M}$ ). Compound $\mathbf{3}$ exhibited moderate inhibitory activity against HL60, SMMC-7721, A-549, MCF-7 and SW480 cells with $\mathrm{IC}_{50}$ values of 12.10, 11.15, 23.64, 31.13 and $14.62 \mu \mathrm{M}$, respectively. However, compound $\mathbf{4}$ displayed significant antiproliferative activity against 
A-549, MCF-7 and SW480 cell lines with $\mathrm{IC}_{50}$ values of $0.88,0.34$ and $0.55 \mu \mathrm{M}$, respectively (Table 4).

Table 4. Cytotoxic activity $\left(\mathrm{IC}_{50}, \mu \mathrm{M}\right)$ of compounds $\mathbf{1 - 4}$ against five tumor cell lines: HL-60, SMMC-7721, A-549, MCF-7, and SW480.

\begin{tabular}{cccccc}
\hline Compound & HL-60 & SMMC-7721 & A-549 & MCF-7 & SW480 \\
\hline $\mathbf{1}$ & $>40$ & $>40$ & $>40$ & $>40$ & $>40$ \\
$\mathbf{2}$ & $>40$ & $>40$ & $>40$ & $>40$ & $>40$ \\
$\mathbf{3}$ & 12.10 & 11.15 & 23.64 & 31.13 & 14.62 \\
$\mathbf{4}$ & $>40$ & $>40$ & 0.88 & 0.34 & 0.55 \\
Cisplatin $^{\mathrm{a}}$ & 2.29 & 11.87 & 12.10 & 11.37 & 16.42 \\
Paclitaxel $^{\mathrm{a}}$ & $<0.008$ & $<0.008$ & $<0.008$ & $<0.008$ & $<0.008$ \\
\hline
\end{tabular}

Positive control.

\section{Acknowledgments}

This work was financially supported by the Key Science and Technology Planning Project of Zigong City (2018YYJC03), Applied Basic Research Program of Sichuan Province (2018JY0049), the National Natural Science Foundation of China (U1702285), Cooperation Project of Wuliangye Group Co., Ltd. and Sichuan University of Science \& Engineering (CXY2019ZR013, CXY2019ZR003).

\section{Supporting Information}

Supporting information accompanies this paper on http://www.acgpubs.org/journal/records-ofnatural-products

\section{ORCID}

Xiao-Yan Ma: 0000-0002-4592-4800

Feng-Xian Yang: 0000-0003-4931-6244

Can Su: 0000-0002-6031-3581

Yijun Yan: 0000-0001-7727-8084

Sheng-Xiong Huang: 0000-0002-3616-8556

\section{References}

[1] H. Nisa, A. N. Kamili, I. A. Nawchoo, S. Shafi, N. Shameem and S. A. Bandh (2015). Fungal endophytes as prolific source of phytochemicals and other bioactive natural products: A review, Microb. Pathogenesis 82, 50-59.

[2] R. X. Tan and W. X. Zou (2001). Endophytes: a rich source of functional metabolites, Nat. Prod. Rep. 18, 448-459.

[3] G. Strobel and B. Daisy (2003). Bioprospecting for microbial endophytes and their natural products, Microbiol. Mo.l Biol. R. 67, 491-502.

[4] J. Bérdy (2012). Thoughts and facts about antibiotics: Where we are now and where we are heading, $J$. Antibiot. 65, 385-395.

[5] Y. Yan, Y.-T. Ma, J. Yang, G. P. Horsman, D. Luo, X. Ji and S.-X. Huang (2016). Tropolone ring construction in the biosynthesis of rubrolone $\mathrm{B}$, a cationic tropolone alkaloid from endophytic Streptomyces, Org. Lett. 18, 1254-1257.

[6] R.-M. Yang, X.-L. Zhang, L. Wang, J.-P. Huang, J. Yang, Y.-J. Yan, J.-Y. Luo, X.-T. Wang and S.-X. Huang (2017). $\alpha$-Pyrone derivatives from a Streptomyces strain resensitize tamoxifen resistance in breast cancer cells, Nat. Prod. Bioprospect. 7, 329-334.

[7] N.-N. Shang, Z. Zhang, J.-P. Huang, L. Wang, J. Luo, J. Yang, T. Peng, Y. Yan, Y.-T. Ma and S.-X. Huang (2018). Glycosylated piericidins from an endophytic streptomyces with cytotoxicity and antimicrobial activity, J. Antibiot. 71, 672-676.

[8] J. M. Andrews and R. Wise (2001). In vitro susceptibility testing of BMS-284756 by the BSAC standardized disc testing method, J. Antimicrob. Chemoth. 48, 322-324. 
[9] A. Monks, D. Scudiero, P. Skehan, R. Shoemaker, K. Paull, D. Vistica, C. Hose, J. Langley, P. Cronise, A. Vaigro-Wolff, M. Gray-Goodrich, H. Campbell, J. Mayo and M. Boyd (1991). Feasibility of a highflux anticancer drug screen using a diverse panel of cultured human tumor cell lines, J. Natl. Cancer I. 83, 757-766.

[10] L. J. Reed and H. Muench (1938). A simple method of estimating fifty percent endpoint, Am. J. Hyg. 27, 493-497.

[11] S. Gomi, S. Amano, E. Sato, S. Miyadoh and Y. Kodama (1994). Novel antibiotics SF2738A, B and C, and their analogs produced by Streptomyces sp, J. Antibiot. 47, 1385-1394.

[12] N. Tsuge, K. Furihata, K. Shin-Ya, Y. Hayakawa and H. Seto (1999). Novel antibiotics pyrisulfoxin A and B produced by Streptomyces californicus, J. Antibiot. 52, 505-507.

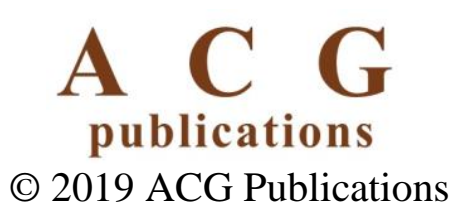

